\title{
REPRESENTASI ORIENTALISME DALAM FILM THE GREAT WALL
}

\author{
Jill Arista Wibisono ${ }^{{ }^{*}}$, Judy Djoko Wahjono Tjahjo ${ }^{1}$, Megawati Wahjudianata ${ }^{1}$ \\ ${ }^{1}$ Prodi Ilmu Komunikasi, Universitas Kristen Petra Surabaya \\ * Penulis korespondensi; Email: jillaristawibisono@gmail.com
}

\begin{abstract}
ABSTRAK
Penelitian ini dilakukan untuk mengetahui bagaimana Orientalisme direpresentasikan melalui film The Great Wall. Pendekatan yang digunakan dalam penelitian ini adalah kualitatif dengan jenis penelitian deskriptif. Metode penelitian yang digunakan adalah semiotika televisi John Fiske melalui 3 level yaitu, level realitas, level representasi, dan level ideologi. Berdasarkan kode-kode tersebut, peneliti melihat adanya konsep orientalisme yang dikemas dengan gaya Barat dalam penggambaran karakter dan budaya Timur melalui film The Great Wall. Hasil penelitian ini memperlihatkan bagaimana Timur sudah dapat berkembang dan tidak tunduk terhadap Barat dalam penggambaran di dalam film. Terlihat dengan pandangan orientalisme yang menjadi ideologi dalam film ini dengan menggambarkan karakter Timur oleh Hollywood sebagai sosok yang berenergi, berinisiatif, tulus, dan mulia. Serta budaya yang disajikan erat dengan oriental budaya Timur dari awal hingga akhir film.
\end{abstract}

Kata kunci: Representasi, orientalisme, semiotika, film, timur, the great wall.

\section{ABSTRACT}

This research was done to find out how the orientalism represented in The Great Wall movie. This research is using qualitative approach with descriptive explanation. Method used in this research is semiotics television of John Fiske through 3 levels, which are reality level, representation level, and ideology level. Through this code, researcher found that the concept of orientalism is more attractived in the character and the orient culture in The Great Wall movie. This study shows how the orient has been able to evolve and are not dependent on the west. It can be shown by the friction of the orient's characters roled by a Hollywood as an energic, initiative, sincere, and noble person. And also every strong the orient culture is displayed from the beginning until the end of the movie.

Keywords: Representation, orientalism, semiotic, film, the great wall.

\section{PENDAhuluan}

Selama ini telah terbentuk image dalam benak kita bahwa Bangsa Barat dianggap sebagai negara yang membawa kemajuan peradaban manusia yang sangat dominan, ditandai dengan adanya industri yang pertama kali terjadi di Inggris. Persepsi inilah yang memunculkan istilah dunia ketiga atau sub-altern. Sub-altern merupakan kelompok-kelompok dalam masyarakat yang menjadi subjek hegemoni kelaskelas yang berkuasa atau bisa disebut juga "mereka yang tidak elit". Munculnya modernisasi dan westernisasi membuat sub-altern semakin bergantung terhadap dunia pertama, yaitu negara-negara maju dalam hal teknologi, budaya, ekonomi, dan segala atribut kehidupan lainnya yang membuat budaya Barat semakin terasa.

Dengan melihat realitas yang terjadi di masyarakat, maka para sineas pun berani mengangkat realitasrealitas tersebut ke dalam sebuah film, karena sebuah film dibuat berdasarkan potret realitas yang terjadi dalam masyarakat. Salah satu industri film yaitu Amerika (Hollywood), telah menghasilkan banyak produk film sejak tahun 1920-an. Tidak heran jika pilar utama dunia perfilman tersebut dapat menghasilkan film-film yang berkualitas dan beragam.

Dalam memproduksi film, Hollywood pun banyak mengangkat film berlatar Timur (the orient), tidak hanya Timur Tengah melainkan Asia Timur juga dijadikan Hollywood sebagai salah satu latar belakang yang diproduksi. Sayangnya, tidak semua film yang berlatar Timur Tengah dan Asia Timur yang dihasilkan oleh Hollywood terlepas dari stereotype Barat yang memandang Timur sebagai sesuatu yang rendah.

Film Karate Kid 2010 dan Big Hero 6 menunjukkan bagaimana Barat dan Timur digambarkan secara berbeda. Dalam kedua film ini, alur cerita dan penokohan dirubah dari filmnya yang asli. Karakter Barat digambarkan lebih superior dibandingkan karakter Timur. Karakter Barat selalu dihubungkan dengan karakter yang cerdas seperti professor yang 
ada dalam film Big Hero 6. Sedandkan, dalam Karate Kid 2010, Timur (Tiongkok) digambarkan sebagai negara yang kotor dan kumuh.

Salah satu film aksi fiksi tahun 2016 yang mengangkat salah satu keajaiban dunia, tembok besar Tiongkok adalah film The Great Wall. The Great Wall adalah film yang menceritakan tentang seorang tentara bayaran Eropa yang awalnya hanya ingin mencuri black powder, justru ikut terlibat dalam peperangan antara pasukan The Great Wall melawan monster Tao Tei.

Keunikan The Great Wall adalah film kolaborasi Amerika-Tiongkok pertama kali yang mengeluarkan biaya besar (US\$ 150 juta) dan film ini masuk ke dalam film popular tahun $2016(I M D B, 2016)$ selain itu film ini juga sangat erat dengan negara Tiongkok yaitu menggunakan latar tempat tembok besar negara Tiongkok yang selama ini selalu diagungkan oleh masyarakat Tionghoa dan dibangun selama lebih dari 1700 tahun itu dengan tujuan melindungi masyarakatnya dari serangan bahaya, baik yang diketahui maupun dari legenda.

Subjek penelitian ini adalah film The Great Wall yang diproduksi oleh Universal Pictures dengan bantuan sutradara Zhang Yimou. Dalam artikel The New Paper menyebutkan bahwa film The Great Wall adalah film Hollywood dengan sentuhan dari Zhang Yimou. Film ini telah diproduksi sebelum Zhang Yimou turut serta dalam pembuatan film ini.

Film bertemakan Timur ini diproduksi oleh tim produksi Barat, hal ini berkaitan dengan orientalisme yang menurut pernyataan Edward Said mengenai kritiknya terhadap ketidakadilan Barat melalui hasil karya nya yang berjudul "Orientalism" yang mengatakan bahwa orientalisme dapat didiskusikan dan dianalisis sebagai institusi yang berbadan hukum untuk menghadapi Timur, berkepentingan membuat pernyataan tentang Timur, membenarkan pandanganpandangan tentang Timur, mendeskripsikan, memposisikan, dan kemudian menguasainya. Dengan kalimat lain, orientalisme adalah cara Barat untuk mendominasi, merestrukturisasi, dan menguasai Timur (Said, 2010, p.4).

Film yang mengandung orientalisme juga pernah diteliti oleh Fauzi Hazmi (2006) dari Universitas Airlangga Surabaya dengan judul penelitian "Representasi Orientalisme dalam film (Analisis Semiotik Mengenai Representasi Orientalisme dalam film Black Hawk Down) yang dalam penelitiannya menyebutkan bahwa film Black Hawk Down juga masih didominasi oleh perspektif atau sudut pandang yang selama ini digunakan oleh film-film barat lainnya dalam memandang negara-negara di Timur, yaitu sebagai negara yang indah dan eksotik tetapi terbelakang dengan rakyat yang miskin, bodoh, dan kejam.

Penggambaran dalam film merupakan hal yang penting untuk diteliti, karena film memiliki dampak terhadap masyarakat, hubungan antara film dan masyarakat selalu dipahami secara linier. Artinya, film selalu mempengaruhi dan membentuk masyarakat berdasarkan muatan pesan (message) di baliknya, tanpa pernah berlaku sebaliknya (Sobur, 2004, p.127). Untuk itu, penelitian tentang representasi perlu dilakukan guna melihat bagaimana orientalisme digambarkan dalam film.

Berdasarkan fakta-fakta diatas, maka peneliti ingin mengetahui penggambaran orientalisme dalam film The Great Wall. Penelitian dalam film ini menggunakan metode semiotika.

\section{TINJAUAN PUSTAKA}

\subsection{Orientalisme}

Orientalisme dapat kita lihat dalam kapasitasnya sebagai "institusi resmi" yang "mengurusi" dunia Timur dengan membuat berbagai pernyataan tentang Timur, melegitimasi beragam asumsi tentang Timur, dan mendeskripsikan Timur, dengan cara mengajarkannya, mencarikannya solusi, dan menguasainya. Singkatnya, kita bisa melihat orientalisme sebagai gaya Barat untuk mendominasi, menata ulang, dan menetapkan kekuasaan mereka terhadap dunia Timur (Said, 2010, p.4).

Menurut pemahaman sederhana, orientalisme adalah sebuah paham yang dihasilkan dari studi orang Barat terhadap apa saja (kekuasaan, ideologi, pengetahuan, dan kebudayaan) tentang oriental (Timur) dalam momen-momen peristiwa pembentukan relasi antara yang Barat dan yang Timur. (Sutrisno Putranto, 2004, p.46).

Orientalisme, pada intinya, adalah pembenaran imperialisme, melukis budaya Timur yang belum berkembang dan entah bagaimana "kurang dari" budaya Barat. Dengan demikian, menjadi tugas "Barat yang maju secara budaya" untuk mempertahankan koloni mereka di negara lain; Mereka menjadi pembenaran dalam pendudukan dan dominasi mereka atas negaranegara lain. 


\subsection{Orientalisme di Media Massa}

Budaya populer Amerika penuh dengan stereotype negatif terhadap orang Arab dan Muslim. Dalam film dan televisi, Arab dikaitkan dengan haus darah akan ketidakjujuran. Dia tampak sebagai individu yang terlalu tinggi, memliki kemampuan, dan akal yang cerdik. Namun pada dasarnya, mereka sadis, berbahaya, dan rendah. Selain itu, digambarkan sebagai pedagang budak, supir unta, pedagang kaki lima, bajingan: ini adalah beberapa peran tradisional Arab di bioskop (Said, 2010, p. 286-287).

Amerika berusaha menggambarkan wilayah Timur sesuai dengan imajinasi mereka. Timur digambarkan unik, kuno, dan penuh misteri. Oleh karena itu, stereotype Barat yang membentuk persepsi audience terhadap Timur hanya berdasarkan sebuah film, tanpa melihat Timur secara langsung (Scurry, 2010, p. 94). Stereotype ini digambarkan sebagai salah satu desakan Hollywood untuk menghapus orang Asia dari narasi mereka sendiri.

\subsection{Representasi}

Representasi adalah konsep yang digunakan dalam proses sosial pemaknaan melalui sistem penandaan yang tersedia: dialog, tulisan, video, film, fotografi, dan sebagainya. Secara ringkas, representasi adalah produksi makna melalui bahasa (Hall, 1997, p.15). Menurut Stuart Hall, representasi juga bisa berarti proses perubahan konsep-konsep ideologi yang abstrak dalam bentuk-bentuk yang konkret. Jadi pandangan-pandangan hidup kita tentang perempuan, anak-anak, atau laki-laki misalnya akan dengan mudah terlihat dari cara kita memberi hadiah ulang tahun kepada teman-teman kita yang laki-laki, perempuan, dan anak-anak, dan lain-lain.

Menurut Stuart Hall, ada dua proses representasi. Pertama, representasi mental yaitu konsep tentang "sesuai" yang ada di kepala kita masing- masing (peta konseptual). Representasi mental ini masih berbentuk sesuatu yang abstrak. Kedua, "bahasa" yang berperan penting dalam proses konstruksi makna. Konsep abstrak yang ada dalam kepala kita harus diterjemahkan dalam "bahasa" yang lazim, supaya kita dapat menghubungkan konsep ide-ide kita tentang sesuatu dengan tanda simbol-simbol tertentu.

Dalam representasi, maka ada dua kemungkinan yang terjadi, pertama, representasi akan mengukuhkan ideologi tersebut atau melalui representasi akan membongkar ideologi tersebut. Melalui representasi, penulis ingin melihat apakah melalui film The Great Wall steoreotype Barat tetap kelihatan atau justru memudar.

\subsection{Semiotika}

Semiotik sebagai suatu model dari ilmu pengetahuan sosial memahami dunia sebagai sistem hubungan yang memiliki unit dasar yang disebut dengan 'tanda'. Dengan kata lain, semiotik mempelajari hakikat tentang keberadaan suatu tanda (Sobur, 2009, p. 87). Menurut Fiske, studi ini dengan jelas menggambarkan bahwa isyarat, dalam hal ini sebuah kata ganti, dihubungkan pada acuannya melalui pikiran seorang pengguna.

Bagi Saussure, tanda merupakan objek fisik dengan sebuah makna, atau untuk menggunakan istilahnya, sebuah tanda seperti atas penanda (signifier) dan petanda (signified). Penanda adalah citra tanda seperti yang kita persepsi (Fiske, 2004, p.65). Dalam hal kategori tanda, Saussure hanya menaruh perhatian pada simbol, karena simbol adalah kata-kata (Fiske, 2004, p.69). Bagi Saussure, ini membantu dalam memahami tanda-tanda dalam film., terutama tandatanda ikonis, yaitu tanda-tanda yang menggambarkan sesuatu.

Jika Saussure terkenal dengan dikotominya (skema diadik), Pierce menggambarkannya melalui segi tiga makna (triangle meaning) yang terdiri atas sign (tanda), object (objek), dan interpretan (interpretant). Menurut Pierce, salah satu bentuk tanda adalah kata. Sedangkan objek adalah sesuatu yang dirujuk tanda. Sementara interpretan adalah tanda yang ada di dalam benak seseorang tentang objek yang dirujuk sebuah tanda. Apabila ketiga elemen makna itu berinteraksi dalam benak seseorang, maka muncullah makna tentang sesuatu yang diwakili oleh tanda tersebut.

Rollan Barthes juga mengembangkan dua tingkatan pertandaan, yang memungkinkan untuk dihasilkannya makna yang juga bertingkat-tingkat, yaitu tingkat denotasi dan konotasi. Denotasi adalah tingkat pertandaan yang menjelaskan hubungan antara penanda dan pertanda. Rujukannya pada realitas, makna yang eksplisit, langsung, pasti, dan yang tampak. Singkatnya, denotasi adalah tanda yang penandanya mempunyai tingkat konvensi atau kesepakatan yang tinggi.

Selain denotasi dan konotasi, Barthes juga melihat makna yang lebih dalam tingkatnya, tetapi lebih bersifat konvensional, yaitu makna-makna yang berkaitan dengan mitos. Mitos dalam pemahaman 
semiotika Barthes adalah pengkodean makna dan nilai-nilai sosial sebagai sesuatu yang dianggap alamiah. (Yuwono, 2004, p. 94-95).

Melalu pengertian semiotika dari para ahli, dapat disimpulkan bahwa semiotika sebagai ilmu untuk memahami makna tanda dan lambang. Dimana makna itu sendiri akan muncul melalui interpretasi masing-masing individu. Tipe-tipe tanda itu sendiri terdiri dari ikon yang berfungsi sebagai penanda yang serupa dengan bentuk aslinya. Indeks merupakan tipe tanda yang memiliki keterkaitan eksistensi terhadap petandanya atau objeknya yang mengisyaratkan penandanya. Tipe tanda yang terakhir adalah simbol sebagai suatu tanda yang sudah ada aturan atau kesepakatan bersama sesuai dengan kebudayaan masing-masing.

\subsection{Kode-Kode Televisi John Fiske}

Dalam semiotika (ilmu tentang tanda) terdapat dua perhatian utama yakni: hubungan antara tanda dan maknanya dan bagaimana suatu tanda dikombinasikan menjadi suatu kode (Fiske dan Hartley, 2003, p. 22). Tanda-tanda yang telah dienkode oleh kodekode sosial yang terkonstruksi dalam tiga level yaitu level realitas (reality) yang terdiri dari kode televisi penampilan (appearance), kostum (dress), riasan (make up), lingkungan (environment), kelakuan (behaviour), dialog (speech), gerakan (gesture), ekspresi (expression), suara (sound).

Kemudian level representasi (representation) terdiri dari kamera (camera), penyuntingan (editing), dan musik (music). Level ketiga yaitu level ideologi, yang didalamnya mengandung kode-kode sosial, diantaranya individualis (individualism), patriarki (patriarchy), kelas (class), ras (race), kapitalisme (capitalism), dan materialism (materialism).

\section{METODE}

\subsection{Konseptualisasi Penelitian}

Penelitian ini menggunakan pendekatan kualitatif, dan metode yang dipakai adalah Semiotika televisi John Fiske. Semiotika sebagai suatu model dari ilmu pengetahuan sosial memahami dunia sebagai sistem hubungan yang memiliki unit dasar yang disebut dengan 'tanda'. Dengan kata lain, semiotik mempelajari hakikat tetntang keberadaan suatu tanda (Sobur, 2009, p. 87).

Dalam penelitian ini, peneliti menggunakan teknik pengumpulan data dokumentasi. Pengumpulan data dokumentasi adalah pengumpulan data yang diperoleh berupa dokumen, teks, karya seni atau gambar (Pawito, 2007). Data yang diperoleh peneliti adalah scene dalam film DVD film The Great Wall. Peneliti akan mengambil shot-shot gambar (capture) dari DVD. Peneliti akan mengumpulkan shot-shot tersebut dan mengelompokkan mereka berdasarkan masingmasing scene dalam film untuk peneliti analisa berdasarkan "The Codes of Television" John Fiske untuk melihat makna dibalik tanda-tanda tersebut.

\subsection{Subjek Penelitian}

Subjek dalam penelitian ini adalah film The Great Wall (2016) yang dikemas dalam format DVD blue ray.

\subsection{Analisis Data}

Dalam melakukan analisis data, peneliti melakukan beberapa tahapan analisis dalam sebuah film (Stokes, 2003, p. 73-75). Pertama, mengumpulkan tanda dan makna dari film "The Great Wall" yang berhubungan dengan orientalisme berdasarkan kode-kode televisi John Fiske. Tahap selanjutnya adalah menjelaskan shot-shot yang telah dikumpulkan dan dilihat melalui tiga level, yaitu: level realitas, level representasi, dan level ideologi.

Peneliti akan melihat bagaimana kode-kode tersebut digambarkan dalam film tersebut. Setelah itu mengartikan makna masing-masing kode secara terpisah. Peneliti akan melihat dari tigal level. Level realitas, level representasi, dan level ideologi yang setiap levelnya memiliki aspek-aspek yang berbeda. Peneliti akan melihat setiap kode yang terdapat dalam setiap level dalam kode televisi John Fiske. Menganalisis kode-kode yang ada dalam film "The Great Wall" berdasarkan pengetahuan dari literatur mengenai orientalisme, pengertian film dan tekniknya.

Membagi makna-makna ke dalam kode-kode yang telah ditentukan, lalu membandingkan dengan cara kode-kode itu digunakan dan yang terakhir adalah menyimpulkan hasil analisa dan temuan peneliti pada bab pembahasan.

\subsection{Temuan Data}

Di dalam penelitian ini, peneliti menggunakan tiga level pengkodean menurut John Fiske. Ketiga level pengkodean tersebut adalah level reality, level representation, dan level ideology. Dalam menggunakan ketiga level tersebut, temuan data yang ditemukan 
oleh peneliti akan dikategorikan dalam beberapa kategori, antara lain penggambaran karakter dan penggambaran budaya.

\section{PENGGAMBARAN KARAKTER TOKOH DALAM FILM THE GREAT WALL}

\subsection{Karakter Timur Selalu Membuat Strategi sebelum Berperang}

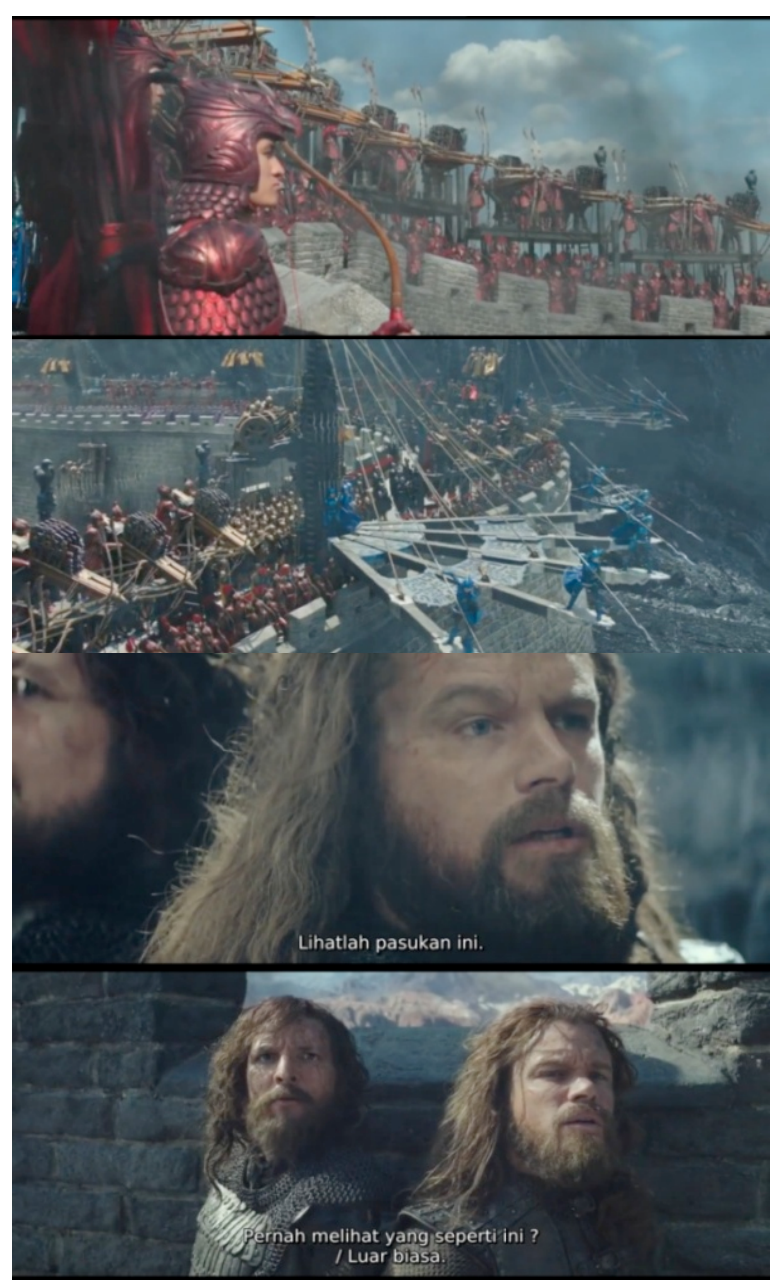

Gambar 1. Persiapan Pasukan The Great Wall Sumber: DVD Film The Great Wall (2016)

Dalam adegan ini terlihat pasukan dalam benteng The Great Wall sedang mempersiapkan posisi untuk melawan bahaya yang akan datang. Melalui level realitas penampilan (appearance) dan pakaian (dress) dalam adegan ini terlihat pasukan dengan pakaian berwarna merah dalam posisi memanah dan pasukan dengan pakaian berwarna biru dalam posisi melompat ke bawah menggunakan pedang dan tali. Penampilan dan pakaian prajurit The Great Wall ini seperti prajurit perang Tionghoa lainnya dalam berperang, yaitu lengkap dengan pakaian baja dan membawa senjata perang.
Melalui adegan ini, terlihat bahwa Timur sudah mempersiapkan diri mereka secara matang dengan membagi para pasukan ke dalam beberapa kelompok. Mereka sudah berlatih dan mempersiapkan strategi untuk melawan musuh yang akan datang. Selain itu, dalam gambar tersebut terlihat tokoh Barat mengagumi pasukan perang The Great Wall tersebut.

\subsection{Karakter Timur yang Tidak Mudah Dikecoh}

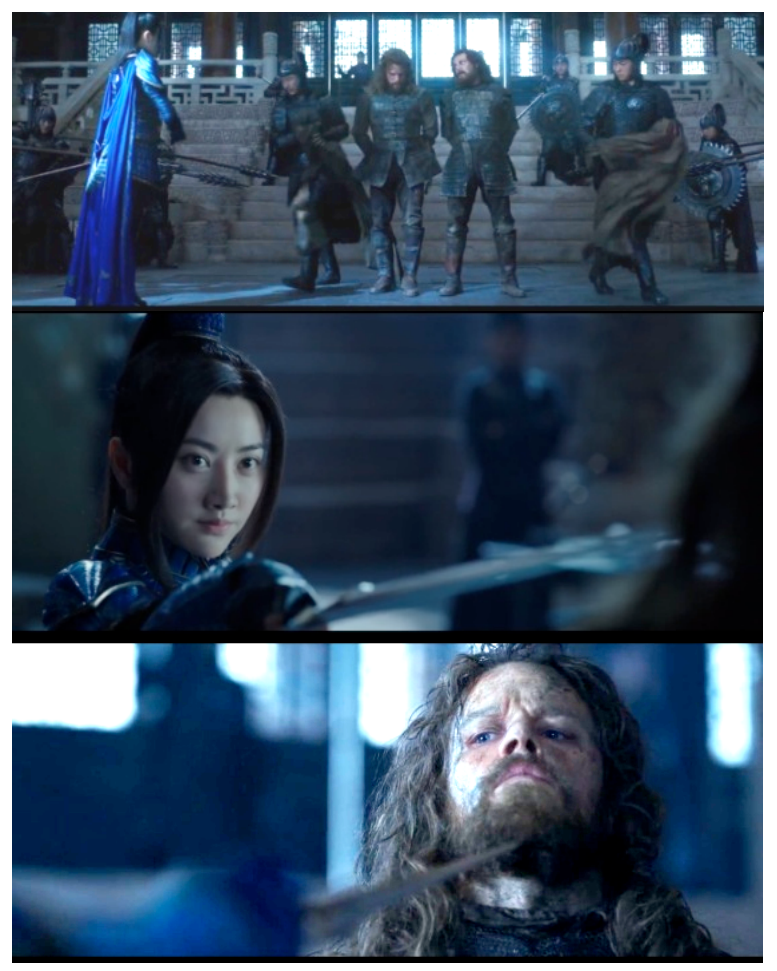

Gambar 2. Komandan Lin Menyodorkan Pedang kepada William

Sumber: DVD Film The Great Wall (2016)

Dalam adegan ini, terlihat tokoh barat (William dan Tovar) sedang berada di dalam tembok besar bersama dengan beberapa prajurit beruang dan salah satu panglima The Nameless Order yaitu, Komandan Lin. Dalam gambar pertama, dua Pasukan Beruang sedang menarik jubah penutup yang digunakan oleh William dan Tovar dan menemui bahwa mereka menggunakan pakaian tentara.

Mengetahui hal tersebut, Komandan Lin langsung menyodorkan pedang ke arah wajah William. Melalui adegan tersebut, terlihat bahwa dalam film ini karakter Timur tidak mudah dikecoh. Tokoh Timur tidak mudah mempercayai orang yang baru mereka kenal. William mengaku sebagai pedagang, namun Komandan Lin tidak percaya begitu saja sehingga ia memeriksa asal-usul William dan Tovar terlebih dahulu. 
4.3 Karakter Timur yang Menghargai Orang Lain

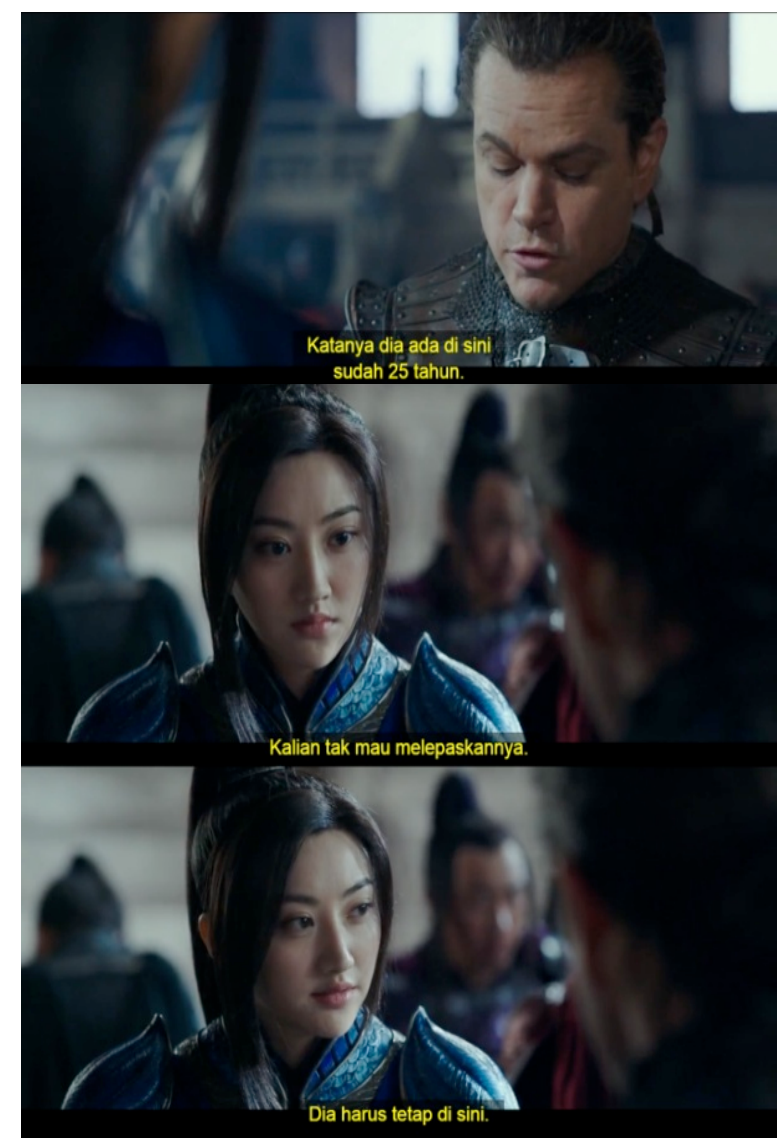

Gambar 3. Komandan Lin dan William sedang Berbincang

Sumber: DVD Film The Great Wall (2016)

Dalam adegan ini terlihat Komandan Lin dan Wiliam sedang berbincang mengenai Sir Ballard. Sir Ballard merupakan salah satu westerner yang sudah lama tinggal di Great Wall bersama pasukan Tiongkok lainnya. Pada adegan tersebut William menanyakan mengenai Sir Ballard yang tidak dilepaskan oleh Komandan Lin.

Melalui dialog yang dilakukan oleh William dan Komandan Lin, seakan-akan Komandan Lin sudah percaya dengan Sir Ballard yang telah lama tinggal bersama mereka, dan tidak mau membiarkannya pergi karena Sir Ballard telah mengajarinya bahasa Inggris dan Latin. Terlihat bahwa Komandan Lin (Timur) juga ingin mempelajari salah satu budaya Barat, yaitu bahasa Inggris dan Latin. Selain itu melalui adegan ini juga memperlihatkan bahwa Timur tidak selalu kuno, mereka mau mempelajari sesuatu hal yang baru dan tidak terpaku pada kebudayaan mereka saja.

\subsection{Pengambaran Budaya dalam film The Great Wall}

Budaya adalah kompleks yang mencakup pengetahuan, kepercayaan, kesenian, moral, hukum, adat istiadat dan kemampuan-kemampuan yang didapatkan manusia sebagai anggota masyarakat. Unsur-unsur budaya secara umum adalah perilaku, gaya berpakaian, kebiasaan, adat istiadat, kepercayaan, dan tradisi. (Taylor dalam Soekanto, 1996, p. 55). Dari pengertian budaya di atas, terdapat unsur-unsur budaya yang digambarkan melalui kode-kode dalam level realitas dan level representasi sesuai dengan bagaimana pandangan Barat terhadap Timur.

\subsection{The Great Wall yang Digambarkan Luas, Megah, dan Panjang}
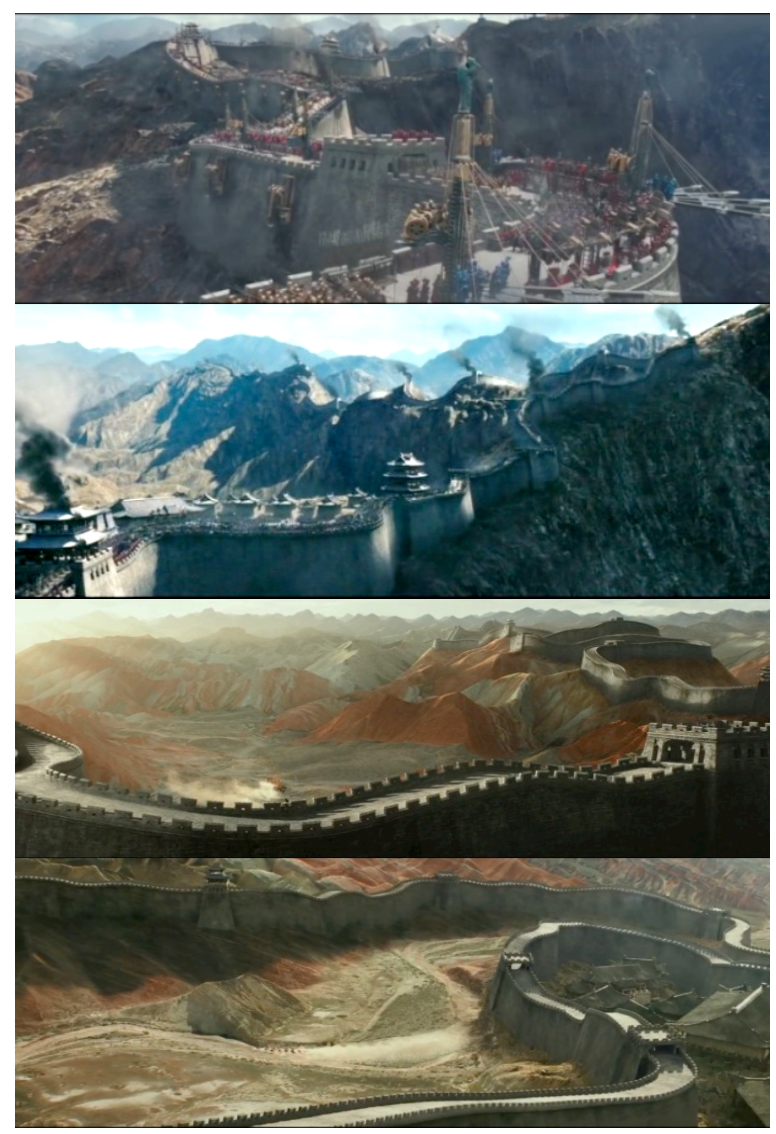

Gambar 4. Tembok Besar Tiongkok dalam film The Great Wall

Sumber: DVD Film The Great Wall (2016)

Dalam adegan ini diperlihatkan bagaimana Tembok Besar Tiongkok (The Great Wall) ditampilkan sebagai benteng pertahanan Tiongkok pada jaman itu. Dalam film ini, dinasti yang sedang mempimpin adalah dinasti Song. Dengan disajikannya salah satu bangunan bersejarah Tembok Besar Tiongkok, secara 
tidak langsung film The Great Wall ingin mengenalkan salah satu bangunan bersejarah yang ada di Tiongkok dengan memberikan informasi singkat mengenai tembok tersebut pada awal film yang menginformasikan mengenai panjang bangunan, dan waktu yang dibutuhkan dalam membangun tempat bersejarah ini.

Teknik pengambilan gambar yang digunakan dalam menunjukkan The Great Wall itu sendiri adalah long shot, wide shot, dan extreme long shot, sehingga terkesan melalui film ini ingin menunjukkan betapa megah, luas, dan panjangnya The Great Wall itu sendiri. Selain itu, dalam adegan yang menampilkan tembok besar dalam film ini selalu diiringi dengan musik gendang Tiongkok atau tiupan ser uling Tiongkok yang sangat khas sehingga mendukung kesan oriental dalam adegan tersebut.

\subsection{Pakaian Emas sebagai Ciri Khas Kaisar Tiongkok}

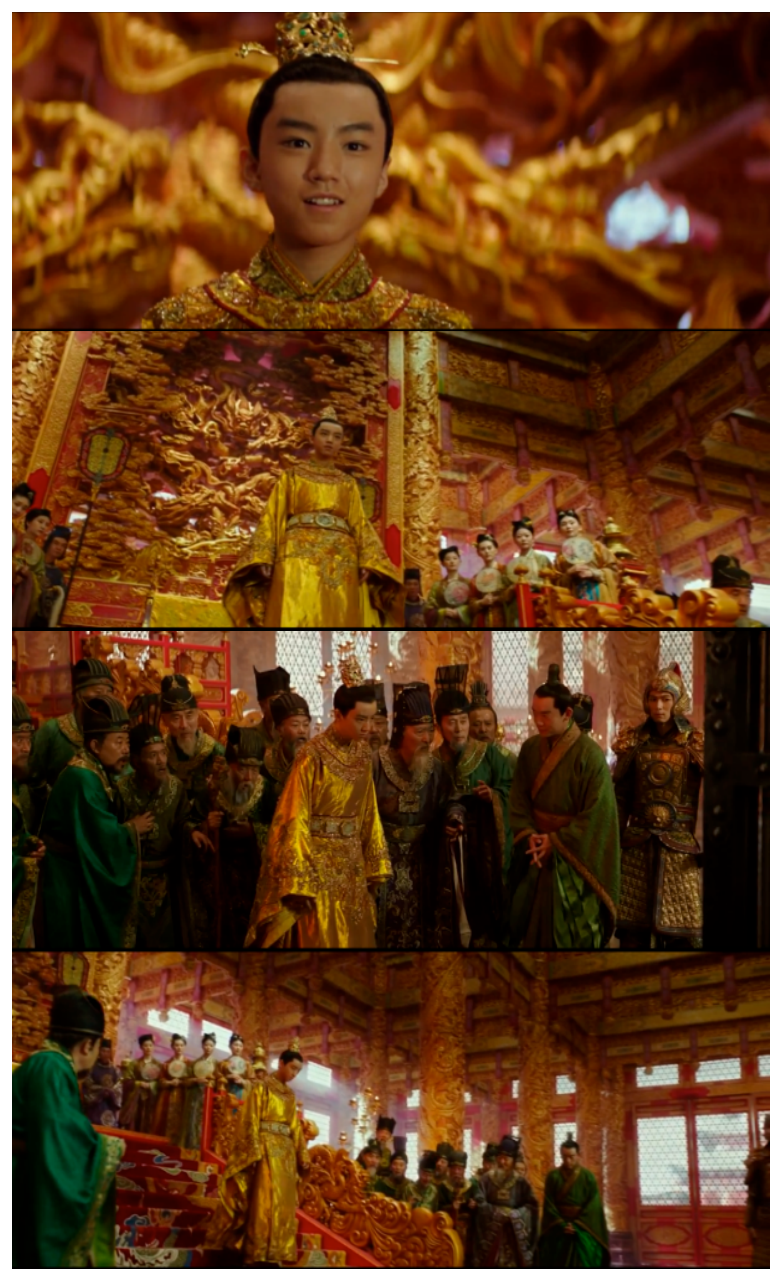

Gambar 5. Pakaian Kaisar dalam Film The Great Wall

Sumber: DVD Film The Great Wall (2016)
Terlihat penampilan kaisar dalam adegan ini adalah seorang kaisar muda yang mengingatkan bahwa dalam kekaisaran Tiongkok, seorang kaisar dapat dipimpin oleh seorang pangeran atau anak yang masih berusia muda. Pengangkatan kaisar terjadi ketika kaisar yang menjabat saat itu meninggal, biasanya putra tertua akan menjadi penggantinya, namun terkadang tidak seperti itu, tergantung dengan keputusan kekeluargaan kaisar dan rakyat saat itu.

Melalui kode pakaian (dress), dalam adegan pakaian yang digunakan oleh kaisar adalah warna emas, dimana kuning/emas adalah warna dari imperial Tiongkok dan ditandai sebagai warna simbolis dari lima kaisar legendaris Tiongkok kuno, yaitu Shui Ren FuXi ShenNong, FuXi NvWa ShenNong, FuXi ZhuRong ShenNong, FuXi ShenNong Gonggong, dan FuXi ShenNong Huang Di.

Melalui adegan ini, ingin memperlihatkan bahwa warna emas sangat dihormati oleh orang-orang Timur, karena warna emas sangat erat kaitannya dengan kekaisaran. Istana, interior istana, bahkan keluarga kekaisaran seringkali didominasi dengan warna emas.

\subsection{Mitos Tao Tei yang Dikembangkan dengan Konsep Western}

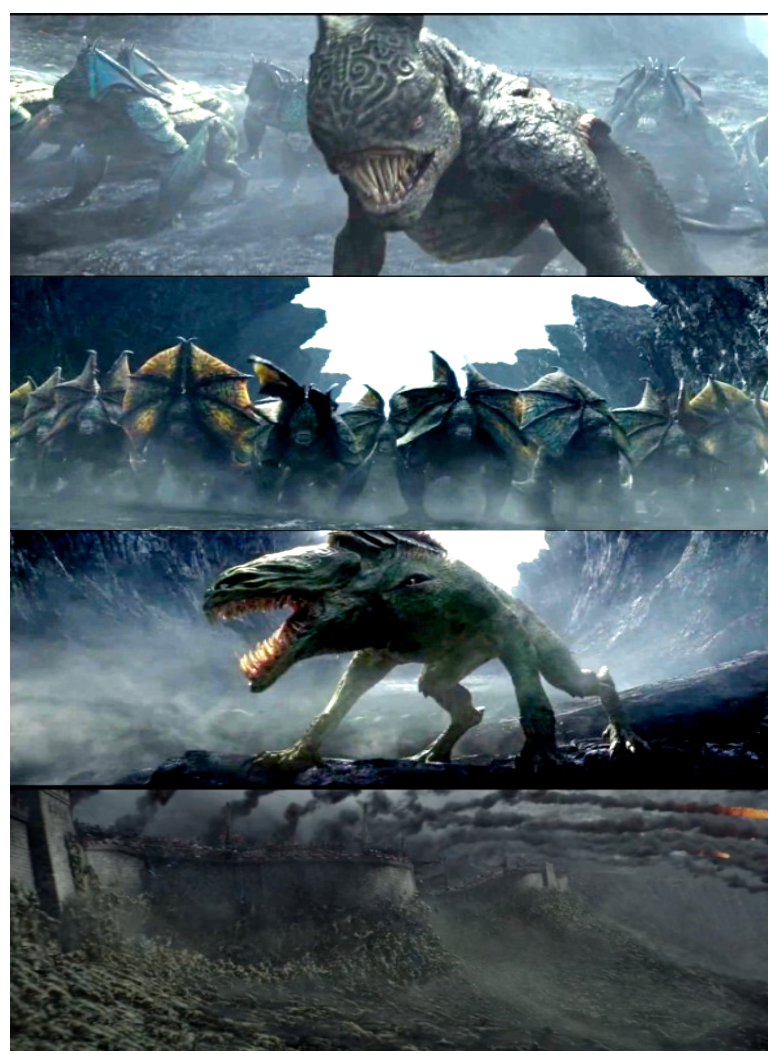

Gambar 6. Monster Tao Tei yang Menyerang The Great Wall

Sumber: DVD Film The Great Wall (2016) 
Monster Tao Tei dalam film ini merupakan musuh besar dari pasukan The Great Wall yang sudah dinanti-nanti. Melalui penampilan, monster Tao Tei ditampilkan dalam tiga jenis. Jenis pertama digambarkan seperti seekor kadal dengan mulut yang besar. Tao Tei tersebut adalah pasukan yang memiliki tugas untuk mencari makan yang nantinya akan diberikan kepada sang ratu.

Tao Tei jenis kedua memiliki tubuh sangat besar, berotot, dan memiliki pelindung di dekat telinganya, Tao Tei jenis kedua ini adalah bodyguard ratu Tao Tei. Dimana dalam film ini, mereka bertugas untuk melindungi ratu mereka. Tao Tei jenis terakhir terlihat pada gambar kiri bawah, dimana Tao Tei itu adalah sang ratu. Wujud dan tubuhnya hampir sama dengan anak buah Tao Tei, hanya saja ia memiliki dua tanduk.

Melalui gesture, terlihat beribu-ribu monster Tao Tei mulai memanjat tembok besar Tingkok, dimana dalam hal ini monster Tao Tei merupakan ancaman yang sangat besar untuk masyarakat Tionghoa.

Melalui film ini, legenda monster Tao Tei kembali diceritakan. Namun konsep Tao Tei memiliki beberapa perubahan dimana monster Tao Tei yang asli adalah seekor naga tanpa badan.

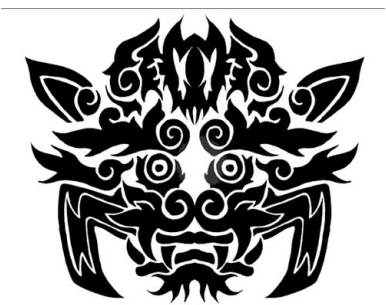

Gambar 7. Wujud Tao Tei yang Asli

Sumber: Google - http://akusenang.com/tag/hewanmitos-Tiongkok/

Sedangkan melalui film ini, monster Tao Tei lebih mirip dengan Vastatosaurus Rex, dan Chlamydosaurus yang berasal Australia. Melalui film ini, monster Tao Tei mengalami perubahan bentuk fisik secara drastis. Dari seekor naga menjadi seekor yang lebih mirip dengan spesies Dinosaurus. Dengan demikian, The Great Wall ingin memasukkan unsur westernisasi melalui monster Tao Tei.

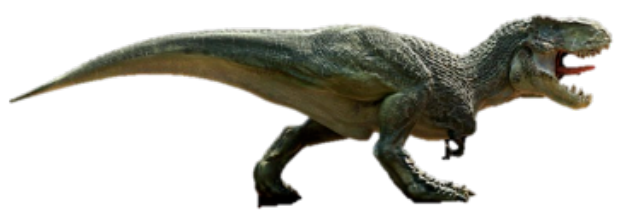

Gambar 8. Vastatosaurus Rex

Sumber: Google - http://kingkong.wikia.com/wiki/ Vastatosaurus rex

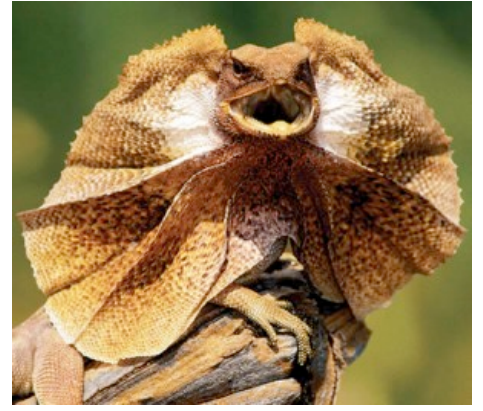

Gambar 9. Chlamydosaurus

Sumber: Google-http://www.australiananimallearning zone.com/frilled-lizard-chlamydosaurus-kingii.htm

\section{ANALISIS DAN INTERPRETASI}

Melalui kategori yang dikelompokkan oleh peneliti dalam melihat penggambaran Timur yaitu penggambaran karakter dan penggambaran budaya yang ada di dalam film The Great Wall. Penggambaran karakter dan budaya Timur terlihat sangat jelas melalui film The Great Wall.

Karakter Timur dalam film The Great Wall digambarkan sebagai krakter yang berinisiatif, tidak mudah dikecoh, dan berenergi, tidak mudah menyerah, dan tidak terpaku pada budaya mereka terusmenerus. Hal ini terlihat dalam beberapa adegan yang memperlihatkan bagaimana pasukan The Great Wall menyiapkan diri mereka untuk melawan monster Tao Tei. Selain itu, mereka tidak mudah percaya dengan pendatang baru seperti William dan Tovar. Setelah pasukan The Great Wall diberikan masukan oleh William, selanjutnya mereka pun melakukan inisiatif dengan strategi yang dibuat oleh pasukan The Great Wall itu sendiri.

Dengan melihat beberapa penggambaran tersebut, karakter Timur dalam film The Great Wall berbeda dengan konsep Orientalisme Said yang menyatakan bahwa karakteristik Timur digambarkan sebagai makhluk yang mudah dikecoh, "tak mempunyai energi dan inisiatif," suka "menjilat". berpura-pura, licik, dan tidak menyenangi binatang. Orang-orang Timur adalah pembohong-pembohong karatan, mereka "malas dan mencurigakan" dan dalam segala hal bertentangan dengan kejernihan, kelurusan, dan kemuliaan (Said, 2010, p.56).

Penggambaran budaya pada film The Great Wall sangat terlihat dengan jelas. Melalui film ini, seolaholah tim produksi Barat ingin mengenalkan budaya Timur kepada audience. Mereka menyajikan berbagai budaya Timur yang sangat kental. Mulai dari 
bangunan The Great Wall, interior istana, bangunan pagoda, dan pakaian yang digunakan dalam film ini.

Nilai moral pun ikut disajikan dalam film ini, dimana dalam film ini digambarkan bahwa karakter Barat digambarkan sebagai orang yang materialistik, sedangkan karakter Timur tidak mengukur segala sesuatunya dengan uang. Sehingga terlihat dalam film ini bahwa karakter Timur digambarkan lebih mulia dibandingkan dengan karakter Barat.

Melalui analisis data yang dilakukan dalam film The Great Wall, peneliti menginterpretasikan melalui film The Great Wall, representasi orientalisme sudah lebih diwarnai oleh Budaya Barat. Melalui film ini memperlihatkan bahwa Bangsa Timur sudah dapat berkembang dan tidak sepenuhnya submissive (tunduk) terhadap Bangsa Barat.

Penggambaran Barat terhadap Timur (orientalisme) dengan stereotype Barat menurut Said (2010) sudah lebih berwarna karena pada film ini karakteristik Bangsa Timur digambarkan sebagai karakter yang berinisisiatif, tidak bodoh, dan rasional. Pada awalnya, film ini terkesan bahwa Bangsa Barat dijadikan hero yang menolong Bangsa Timur, namun jika diteliti lebih dalam, justru karakteristik Barat dalam film inilah yang digambarkan sebagai pencuri, pembohong, dan licik.

Walaupun film ini produksi Barat, namun netizen mengakui bahwa film ini sangat terasa dan dekat dengan nuansa Asia yang memperlihatkan landscapelandscape yang sangat erat kaitannya dengan Asia, seperti The Great Wall, istana kerajaan, dan pemandangan yang lainnya. Selain itu, netizen juga banyak yang merasa bahwa aktor Barat dalam film ini dipaksakan. Harusnya film ini hanya melibatkan aktor dari Asia.

Oleh karena itu, tidak semuanya pemaksaan Hollywood dengan melibatkan aktornya dinilai bagus oleh para penonton, justru terlihat tidak pas dan memaksakan kehendaknya yang tidak sesuai dengan cerita film ini. Selain itu, netizen lebih terlihat tertarik jika film ini hanya dimainkan oleh aktor-aktris dari Asia saja, tanpa melibatkan aktor dari Barat.

Melalui film The Great Wall, terlihat bahwa Amerika dan Tiongkok kembali menjalin hubungan kerja sama dalam industri film, karena Tiongkok merupakan salah satu negara yang sedang maju dalam bidang industri perfilman. Semakin terlihat bahwa tidak semua Bangsa Timur selalu dipandang rendah, namun Bangsa Timur sudah lebih berkembang. Oleh sebab itu, The Great Wall dijadikan sebagai film yang bergenre Chi-Wood (China-Hollywood) dimana adanya pencampuran budaya antara Bangsa Barat dan Bangsa Timur.

Dengan demikian, film menjadi salah satu alat komunikasi yang dapat menyampaikan pesan dari pihak-pihak tertentu. Representasi orientalisme dalam film The Great Wall digambarkan menjadi lebih baru dalam menyampaikan pengenalan budaya. Jadi, tidak ada penampilan yang berlebihan (superior/inferior) diantara dua suku bangsa tersebut.

\section{KESIMPULAN}

Melalui penelitian ini peneliti menarik kesimpulan bahwa pandangan orientalisme dalam film lebih diwarnai oleh Budaya Barat melalui penggambaran karakter dan penggambaran budaya. Karakteristik Timur dalam film ini sudah digambarkan menjadi karakteristik yang berinisiatif, rasional, enerjik, dan penuh dengan kemuliaan, berbeda dengan pandangan orientalisme Said yang mengatakan Timur sebagai karakter yang irasional, bermalas-malasan, pembohong karatan, dsb. Melalui film The Great Wall karakteristik Barat justru digambarkan sebagai karakteristik yang licik, pembohong, irasional dan seorang pencuri.

Dalam film ini terlihat bagaimana Barat mengagumi budaya Timur yang tidak dimiliki oleh Bangsa Barat yaitu ketika pasukan-pasukan The Great Wall mempersiapkan diri mereka untuk berperang, dan pada saat upacara kematian Komandan Shao yang memperlihatkan ekspresi dari William dan Tovar yang menunjukkan rasa kagum. Jadi tidak selamanya, Bangsa Timur selalu submissive (tunduk) kepada Bangsa Barat.

Melalui film The Great Wall, terlihat bahwa Amerika dan Tiongkok kembali menjalin hubungan kerja sama dalam industri film, karena Tiongkok merupakan salah satu negara yang sedang maju dalam bidang insutri perfilman. Semakin terlihat bahwa sekarang tidak semua Bangsa Timur selalu dipandang rendah, namun Bangsa Timur lebih berkembang. Terlepas dari kepentingan material masing-masing, melalui film ini, Cina berkesempatan untuk memperkenalkan lebih kepada seluruh dunia mengenai kebudayaannya yang sangat kuat. 


\section{DAFTAR PUSTAKA}

Fiske, J. and Harley J. (2003). Reading Television. London: Routledge.

Fiske, J. (2004). Cultural and Communication Studies. Yogyakarta: Jalasutra.

Hall, Stuart. (1997). Representation: Cultural Representations and Signifying Practices. Beverly Hills: SAGE Publications Ltd.

Hazmi, F. (2007). Representasi Orientalisme dalam film (Analisis Semiotik Mengenai

Representasi Orientalisme dalam film Black Hawk Down).

Pawito. (2007). Penelitian Komunikasi Kualitatif. Bandung: PT. Remaja Rosdakarya.
Putranto, S. (2004). Hermeneutika pascakolonial: Soal Identitas. Jogjakarta: Kanisius.

Said. E. W. (2010). Orientalisme. Bandung: Pustaka Salman.

Scurry, Samuel. (2010). Orientalism in America Cinema: Providing an Historical and Geographical Context for Post-Colonial Theory. (Paper 789).

Sobur, Alex. (2004). Semiotika Komunikasi. Bandung: PT. Remaja Rosdakarya. ----- (2009). Analisis Teks Media. Bandung: PT. Remaja Rosdakarya.

Stokes, J. (2003) How To Do Media and Cultural Studies. London: SAGE Publications Ltd.

Yuwono, Untung. (2004). Semiotika Budaya. Jakarta: Pusat Kemasyarakatan dan Budaya UI. 